\title{
Confirmation of the crystal structure of $\mathrm{PrNi}_{9} \mathrm{Si}_{4}$
}

\author{
Bohdana BELAN ${ }^{1}$, , Svitlana PUKAS ${ }^{1}$, Mykola MANYAKO $^{1}$, Anna GAGOR $^{2}$, Roman GLADYSHEVSKII $^{1}$ \\ ${ }^{1}$ Department of Inorganic Chemistry, Ivan Franko National University of Lviv, \\ Kyryla i Mefodiya St. 6, 79005 Lviv, Ukraine \\ ${ }^{2}$ Institute of Low Temperature and Structure Research, Polish Academy of Sciences, \\ P.O. Box 1410, 50-950 Wroctaw 2, Poland \\ * Corresponding author. Tel.: +380-32-2394506; e-mail: bohdana.belan@lnu.edu.ua
}

Received May 19, 2017; accepted June 27, 2017; available on-line April 1, 2018

The crystal structure of $\mathrm{PrNi}_{9} \mathrm{Si}_{4}$ was refined on $\mathrm{X}$-ray single-crystal diffraction data. It was confirmed that the compound crystallizes in the tetragonal system, space group $I 4 / \mathrm{mcm}(a=7.8335(11), c=11.466(2) \AA$, $Z=4 ; R=0.0284, w R=0.0703$ for 209 independent reflections and 25 variables). The structure belongs to the structure type $\mathrm{CeNi}_{8.5} \mathrm{Si}_{4.5}$, but shows ordered distribution of the atoms with the $\mathrm{Si}$ atoms occupying exclusively one of the sites in Wyckoff position $16 l$.

Praseodymium / Nickel / Silicon / X-ray single crystal diffraction / Crystal structure

\section{Introduction}

The interaction of praseodymium with nickel and silicon has not been studied systematically. The existence of 18 ternary compounds has been reported in the Pr-Ni-Si system [1-3] (Table 1). The crystal structures of the following compounds have been refined on X-ray diffraction data: $\mathrm{PrNi}_{9} \mathrm{Si}_{4}$ (powder), $\mathrm{PrNi}_{2} \mathrm{Si}_{2}$ (single-crystal, powder), $\mathrm{PrNiSi}_{2}$ (powder), $\mathrm{Pr}_{6} \mathrm{Ni}_{7} \mathrm{Si}_{4} \quad$ (single-crystal), $\mathrm{Pr}_{3} \mathrm{NiSi}_{3}$ (powder), $\operatorname{Pr}_{14} \mathrm{Ni}_{6} \mathrm{Si}_{11}$ (single-crystal), $\operatorname{Pr}_{15} \mathrm{Ni}_{7} \mathrm{Si}_{10}$ (singlecrystal), $\quad \operatorname{Pr}_{5} \mathrm{Ni}_{1.9} \mathrm{Si}_{3}$ (single-crystal; $\operatorname{Pr}_{5} \mathrm{Ni}_{2} \mathrm{Si}_{3}$ : powder), $\quad \operatorname{Pr}_{6} \mathrm{Ni}_{1.76} \mathrm{Si}_{3}$ (single-crystal; $\operatorname{Pr}_{6} \mathrm{Ni}_{1.57} \mathrm{Si}_{3}$ : powder). The structure of $\mathrm{PrNi}_{0.5} \mathrm{Si}_{1.5}$ has fixed coordinates for all the atoms.

In 1969, Bodak and Gladyshevskii [4] reported that the ternary systems $R-\mathrm{Ni}-\mathrm{Si}(R=\mathrm{La}, \mathrm{Ce}, \mathrm{Pr}, \mathrm{Nd}$, $\mathrm{Sm}$, and $\mathrm{Eu})$ contain a ternary compound of composition $\sim R \mathrm{Ni}_{8.5} \mathrm{Si}_{4.5}$ with a tetragonal structure closely related to the cubic $\mathrm{NaZn}_{13}$-type [5]. These compounds show limited homogeneity ranges along the isoconcentrate 7.14 at.\% $R$. Ten years later the structure of the compound with Ce was solved from $\mathrm{X}$-ray single-crystal diffraction data: own structure type $\mathrm{CeNi}_{8.5} \mathrm{Si}_{4.5}$, Pearson symbol $t 156$, space group I4/mcm, $a=7.857, c=11.503 \AA$ [6]. The Ce atoms were located in Wyckoff position $4 a$, the main part of the $\mathrm{Ni}$ atoms in positions $16 l$ and $16 k$, and the $\mathrm{Si}$ atoms on a second site in Wyckoff position $16 l$. Wyckoff position $4 d$ was found to be occupied by a statistical mixture of $\mathrm{Ni}$ and $\mathrm{Si}$ atoms, for which the ratio was fixed to $1: 1$. More recently, similar atom distributions were reported for the compounds with $\mathrm{La}$ $(a=7.8723, \quad c=11.4807 \AA) \quad[7], \quad \operatorname{Pr} \quad(a=7.8377$, $c=11.4861 \AA), \mathrm{Nd}(a=7.836, c=11.457 \AA)$ [8], and Eu $(a=7.8205, c=11.525 \AA)$ [9]. However in these cases the composition was $R \mathrm{Ni}_{9} \mathrm{Si}_{4}$ and the atom distribution fully ordered, Wyckoff position $4 d$ being occupied exclusively by $\mathrm{Ni}$ atoms.

The aim of the present work was to confirm the ordered atom arrangement in the structure of $\mathrm{PrNi}_{9} \mathrm{Si}_{4}$ based on X-ray single-crystal diffraction data.

\section{Experimental}

An alloy of nominal composition $\operatorname{Pr}_{7.1} \mathrm{Ni}_{60.8} \mathrm{Si}_{32.1}$ $\left(\mathrm{PrNi}_{8.5} \mathrm{Si}_{4.5}\right)$ with a total mass of $2 \mathrm{~g}$ was prepared from high-purity elements (Pr: 99.98 wt.\%, Ni: 99.99 wt.\%, Si: 99.9999 wt.\%) by arc melting in a water-cooled copper crucible under a purified argon atmosphere, using $\mathrm{Ti}$ as getter and a tungsten electrode. To achieve high efficiency of the interaction between the components the sample was melted twice. The composition of the sample was controlled by comparing the mass of the alloy with the total mass of the initial load. The weight loss did not exceed $2 \%$ after melting. The alloy was annealed for two weeks at $600^{\circ} \mathrm{C}$ under vacuum in a quartz ampoule and subsequently quenched into cold water. 
A single crystal, suitable for X-ray investigation, was extracted from the alloy. The first stage of the investigation, by Laue and rotation methods (Mo $K$ radiation), indicated tetragonal symmetry and yielded approximate values of the lattice parameters. X-ray diffraction data was collected on a KUMA KM-4 four-circle diffractometer equipped with a CCD detector, using graphite-monochromatized Mo $K \alpha$ radiation $(\lambda=0.71073 \AA)$. The crystal structure was solved by the Patterson method and refined by the full-matrix least-squares method using the program SHELXL-97 [10]. After the data collection, the single crystal was analyzed by EDX spectroscopy with a Leica420i scanning electron microscope. No impurity elements heavier than sodium were detected. The structure drawings were made with the program ATOMS [11].

\section{Results and discussion}

The EDX analysis showed that the composition of the single crystal did not deviate significantly from the stoichiometry $\mathrm{PrNi}_{9} \mathrm{Si}_{4}$. The crystal structure of the compound was refined in the space group $14 / \mathrm{mcm}$ and it was confirmed that it belongs to the $\mathrm{CeNi}_{8.5} \mathrm{Si}_{4.5}$ type. Experimental details of the data collection and structure refinement of $\mathrm{PrNi}_{9} \mathrm{Si}_{4}$ are presented in
Table 2. Atomic coordinates and displacement parameters for $\mathrm{PrNi}_{9} \mathrm{Si}_{4}$ are given in Table 3, whereas interatomic distances, coordination numbers, and coordination polyhedra are listed in Table 4. Like the refinement on X-ray powder diffraction data [8], the refinement on single-crystal data showed complete ordering of the $\mathrm{Ni}$ and $\mathrm{Si}$ atoms: three sites are occupied by $\mathrm{Ni}$ atoms $(16 l, 16 k$, and $4 d)$ and one site by $\mathrm{Si}$ atoms $(16 l)$.

The crystal structure of $\mathrm{PrNi}_{9} \mathrm{Si}_{4}$ is a derivative of the cubic $\mathrm{NaZn}_{13}$-type. The coordination number of the $\mathrm{Pr}$ atoms is 24 and the coordination polyhedron [ $\left.\mathrm{PrNi}_{16} \mathrm{Si}_{8}\right]$ is analogous to the coordination polyhedron of the $\mathrm{Na}$ atoms in the $\mathrm{NaZn}_{13}$ structure. The coordination number of the Ni1, Ni3, and $\mathrm{Si}$ atoms is 13 , which is also the case for the $\mathrm{Zn}$ atoms in the $\mathrm{NaZn}_{13}$ structure. The coordination polyhedron of site $\mathrm{Ni3}$ atom is an icosahedron.

According to $[12,13]$ (which cover data published up to 2000), the structure type $\mathrm{NaZn}_{13}$ has three ternary derivatives. The structure of $\mathrm{CaCu}_{6.5} \mathrm{Al}_{6.5}$ [14] is a partly disordered derivative with the same cubic symmetry as the prototype (space group $F m-3 c$ ), whereas the structures of $\operatorname{Pr}_{0.693} \mathrm{Co}_{9} \mathrm{Ge}_{4}$ [15] and $\mathrm{CeNi}_{8.5} \mathrm{Si}_{4.5}$ [5] exhibit tetragonal symmetry (space group $I 4 / \mathrm{mcm}$ ). The arrangement of transition metal and $p$-element atoms is ordered in the former, but partly disordered in the latter.

Table 1 Crystallographic parameters of ternary compounds reported in the $\mathrm{Pr}-\mathrm{Ni}-\mathrm{Si}$ system [2].

\begin{tabular}{|c|c|c|c|c|c|c|c|c|}
\hline Compound & $\begin{array}{c}\text { Structure } \\
\text { type }\end{array}$ & $\begin{array}{l}\text { Pearson } \\
\text { symbol }\end{array}$ & $\begin{array}{l}\text { Space } \\
\text { group }\end{array}$ & $a, \AA$ & $b, \AA$ & $c, \AA$ & $\begin{array}{c}\text { Level of structure } \\
\text { determination }\end{array}$ & Method \\
\hline $\mathrm{PrNi}_{7.8} \mathrm{Si}_{5.2}$ & $\mathrm{NaZn}_{13}$ & $c F 112$ & $F m-3 c$ & 11.19 & - & - & cell & powder \\
\hline PrN & $\mathrm{CeNi}_{8.5} \mathrm{Si}_{4.5}$ & $t I 56$ & $I 4 / \mathrm{mcm}$ & 7.8377 & - & 11.4861 & complete & der \\
\hline $\mathrm{PrNi}_{8.6} \mathrm{Si}_{2.4}$ & $\mathrm{CeNi}_{8.6} \mathrm{Si}_{2.4}$ & $t I 48$ & $I 4_{1} /$ amd & 9.817 & - & 6.249 & cell & wder \\
\hline $\mathrm{Pr}_{2} \mathrm{Ni}_{8.5} \mathrm{Si}_{8.5}$ & $\mathrm{Th}_{2} \mathrm{Ni}_{17}$ & $h P 38$ & $\mathrm{~Pb}_{3} / \mathrm{mmc}$ & 8.399 & - & 8.089 & cell & powder \\
\hline $\mathrm{PrNi}_{2} \mathrm{Si}_{2}$ & $\mathrm{CeAl}{ }_{2} \mathrm{Ga}_{2}$ & $t 10$ & $I 4 / m n$ & 4.047 & - & 9.621 & complete & single-crystal \\
\hline & $\mathrm{Ce} \mathrm{Al}_{2} \mathrm{Ua}_{2}$ & 1110 & $14 / \mathrm{mmm}$ & 4.047 & - & 9.626 & $\operatorname{com} \mathrm{l}$ & vder \\
\hline $\mathrm{PrNiSi}_{2}$ & $\mathrm{CeNiSi}_{2}$ & $o S 16$ & $\mathrm{Cmcm}$ & 4.1329 & 16.4453 & 4.0466 & complete & der \\
\hline $\mathrm{Pr}_{3} \mathrm{Ni}_{6} \mathrm{Si}_{2}$ & $\mathrm{Ce}_{3} \mathrm{Ni}_{6} \mathrm{Si}_{2}$ & $c I 44$ & Im-3m & 8.976 & - & - & cell & powder \\
\hline $\operatorname{PrNi}_{0.25} \mathrm{Si}_{1.75}$ & $\alpha-\mathrm{ThSi}_{2}$ & $t I 12$ & $I 4_{1} /$ amd & 4.187 & - & 13.846 & cell & powder \\
\hline $\begin{array}{c}\operatorname{PrNi}_{0.5-0.75} \times \\
\mathrm{Si}_{1.5-1.25}\end{array}$ & $\mathrm{AlB}_{2}$ & $h P 3$ & $P 6 / \mathrm{mmm}$ & $\begin{array}{c}4.021- \\
4.050\end{array}$ & - & $\begin{array}{c}4.025- \\
4.181\end{array}$ & cell & powder \\
\hline PrNiSi & $\mathrm{LaPtSi}$ & $t I 12$ & $I 4_{1} m d$ & 4.109 & - & 13.970 & cell & powder \\
\hline $\operatorname{PrNi}_{1.75} \mathrm{Si}_{0.25}$ & $\mathrm{MgZn}_{2}$ & $h P 12$ & $\mathrm{PG}_{3} / \mathrm{mmc}$ & 5.227 & - & 7.709 & cell & powder \\
\hline $\operatorname{Pr}_{6} \mathrm{Ni}_{7} \mathrm{Si}_{4}$ & $\mathrm{Pr}_{6} \mathrm{Ni}_{7} \mathrm{Si}_{4}$ & oP68 & Pbcm & 5.888 & 7.4265 & 29.558 & complete & single-crystal \\
\hline $\mathrm{Pr}_{3} \mathrm{NiSi}_{3}$ & $\mathrm{Ba}_{3} \mathrm{Al}_{2} \mathrm{Ge}_{2}$ & $o I 14$ & Immm & 4.060 & 4.277 & 17.982 & complete & powder \\
\hline $\operatorname{Pr}_{14} \mathrm{Ni}_{6} \mathrm{Si}_{11}$ & $\operatorname{Pr}_{14} \mathrm{Ni}_{6}$ & $m S 12$ & $C 2$ & 3.991 & $\begin{array}{c}4.2328 \\
\beta=113.72^{\circ}\end{array}$ & 30 & complet & $\sin$ \\
\hline $\mathrm{Pr}_{15} \mathrm{Ni}_{7} \mathrm{Si}_{10}$ & $\operatorname{Pr}_{15} \mathrm{Ni}_{7} \mathrm{Si}_{10}$ & $h P 64$ & $P 6_{3} / m$ & 19.881 & - & 4.2554 & complete & single-crystal \\
\hline $\operatorname{Pr}_{7} \mathrm{~N}$ & $\mathrm{Ce}_{7} \mathrm{Ni}_{2} \mathrm{Si}_{5}$ & $o P 56$ & Pnma & 23.32 & 4.302 & 13.84 & cell & powder \\
\hline $\mathrm{Pr}_{5} \mathrm{Ni}_{2} \mathrm{Si}_{3}$ & $\mathrm{Ce}_{5} \mathrm{Ni}_{2} \mathrm{Si}_{3}$ & $h P 40$ & $P 6_{3} / m$ & 15.932 & - & 4.258 & complete & powder \\
\hline $\operatorname{Pr}_{5} \mathrm{Ni}_{1.9} \mathrm{Si}_{3}{ }^{\mathrm{a}}$ & $\mathrm{La}_{5} \mathrm{Ni}_{1.75} \mathrm{Si}_{3}$ & $h P 44$ & $P 6_{3} / m$ & 15.9268 & - & 4.2553 & complete & single-crystal \\
\hline $\mathrm{Pr}_{6} \mathrm{Ni}_{2} \mathrm{Si}_{3}$ & $\mathrm{Ce}_{6} \mathrm{Ni}_{2} \mathrm{Si}_{3}$ & $h P 22$ & $P 6_{3} / m$ & 12.005 & - & 4.273 & cell & powder \\
\hline $\mathrm{Pr}_{6} \mathrm{Ni}_{1.76} \mathrm{Si}_{3}{ }^{\mathrm{a}}$ & $\mathrm{Pr}_{6} \mathrm{Ni}_{1.76} \mathrm{Si}_{3}$ & $h P 24$ & $P 6_{3} / m$ & 12.003 & - & 4.2939 & complete & single-crystal \\
\hline $\mathrm{Pr}_{6} \mathrm{Ni}_{1.57} \mathrm{Si}_{3}{ }^{\mathrm{a}}$ & $\mathrm{Nd}_{6} \mathrm{Ni}_{1.66} \mathrm{Si}_{3}$ & $h P 26$ & $P 6_{3} / m$ & 12.003 & - & 4.2939 & complete & powder \\
\hline
\end{tabular}

${ }^{a}$ part of the solid solution of the preceding compound 
Table 2 Crystal data, data collection and refinement of $\mathrm{PrNi}_{9} \mathrm{Si}_{4}$.

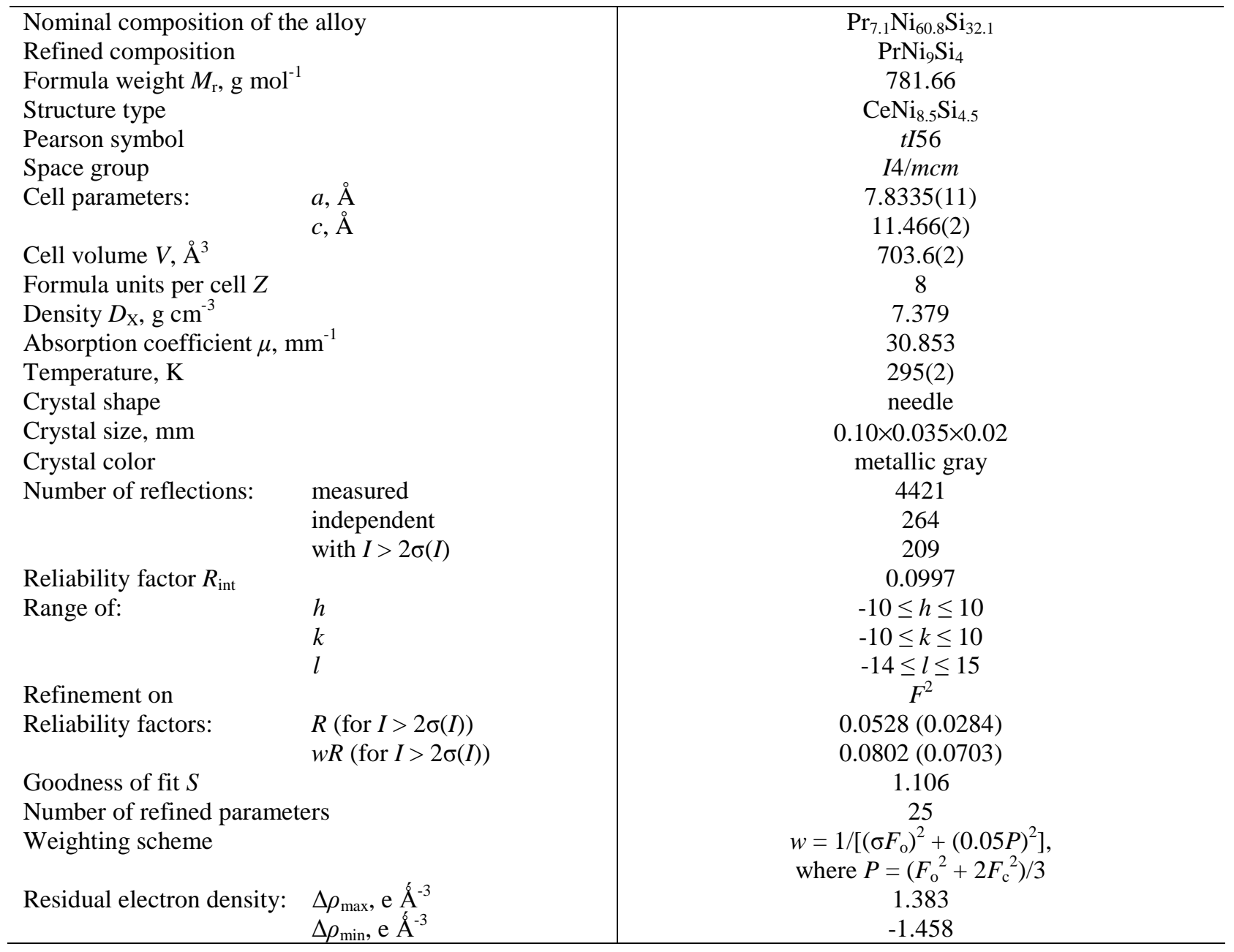

Table 3 Atomic coordinates and displacement parameters for $\mathrm{PrNi}_{9} \mathrm{Si}_{4}$ : structure type $\mathrm{CeNi}_{8.5} \mathrm{Si}_{4.5}$, Pearson symbol tI56, space group I4/mcm, $a=7.8335(11), c=11.466(2) \AA(a=7.8377(12), c=11.4861(17) \AA$, atomic coordinates in italics are from X-ray powder diffraction [8]).

\begin{tabular}{|c|c|c|c|c|c|}
\hline Site & $\begin{array}{l}\text { Wyckoff } \\
\text { position }\end{array}$ & $x$ & $y$ & $z$ & $U_{\text {eq. }}, \AA^{2}$ \\
\hline $\mathrm{Pr}$ & $4 a$ & 0 & 0 & $1 / 4$ & $0.0063(4)$ \\
\hline Ni1 & $16 l$ & $\begin{array}{l}0.63006(13) \\
0.6302(2)\end{array}$ & $\begin{array}{l}0.13006(13) \\
0.1302(2)\end{array}$ & $\begin{array}{c}0.18386(13) \\
0.18521(17)\end{array}$ & $0.0071(4)$ \\
\hline $\mathrm{Ni} 2$ & $16 k$ & $\begin{array}{l}0.06940(19) \\
0.0691(3)\end{array}$ & $\begin{array}{l}0.20269(17) \\
0.2028(3)\end{array}$ & 0 & $0.0093(4)$ \\
\hline $\mathrm{Ni3}$ & $4 d$ & 0 & $1 / 2$ & 0 & $0.0076(6)$ \\
\hline $\mathrm{Si}$ & $16 l$ & $\begin{array}{l}0.1704(3) \\
0.1714(4)\end{array}$ & $\begin{array}{l}0.6704(3) \\
0.6714(4)\end{array}$ & $\begin{array}{l}0.1195(3) \\
0.1193(5)\end{array}$ & $0.0095(7)$ \\
\hline
\end{tabular}

\begin{tabular}{c|c|c|c|c|c|c}
\hline Site & $U_{11}, \AA^{2}$ & $U_{22}, \AA^{2}$ & $U_{33}, \AA^{2}$ & $U_{12}, \AA^{2}$ & $U_{13}, \AA^{2}$ & $U_{23}, \AA^{2}$ \\
\hline $\mathrm{Pr}$ & $0.0051(4)$ & $0.0051(4)$ & $0.0087(6)$ & 0 & 0 & 0 \\
$\mathrm{Ni} 1$ & $0.0079(6)$ & $0.0079(6)$ & $0.0056(7)$ & $0.0002(5)$ & $-0.0018(4)$ & $0.0018(4)$ \\
$\mathrm{Ni} 2$ & $0.0078(8)$ & $0.0090(8)$ & $0.0112(8)$ & $0.0002(6)$ & 0 & 0 \\
$\mathrm{Ni3}$ & $0.0070(8)$ & $0.0070(8)$ & $0.0088(13)$ & $0.0031(12)$ & 0 & 0 \\
$\mathrm{Si}$ & $0.0097(9)$ & $0.0097(9)$ & $0.0090(16)$ & $0.0021(13)$ & $0.0007(9)$ & $-0.0007(9)$ \\
\hline
\end{tabular}


Table 4 Interatomic distances, coordination numbers, and coordination polyhedra for $\mathrm{PrNi}_{9} \mathrm{Si}_{4}$.

\begin{tabular}{|c|c|c|c|c|c|c|c|c|c|}
\hline \multicolumn{2}{|r|}{ Atoms } & $\delta, \AA$ & $\mathrm{CN}$ & Polyhedron & \multicolumn{2}{|r|}{ Atoms } & $\delta, \AA$ & $\mathrm{CN}$ & Polyhedron \\
\hline $\mathrm{Pr}$ & $\begin{array}{l}-8 \mathrm{Ni} 1 \\
-8 \mathrm{Si} \\
-8 \mathrm{Ni} 2\end{array}$ & \begin{tabular}{|l|}
$3.1639(9)$ \\
$3.269(3)$ \\
$3.3217(9)$
\end{tabular} & 24 & & $\mathrm{Ni3}$ & $\begin{array}{l}-4 \mathrm{Si} \\
-4 \mathrm{Ni} 2 \\
-4 \mathrm{Ni} 1\end{array}$ & $\begin{array}{l}2.333(3) \\
2.392(2) \\
2.554(1)\end{array}$ & 12 & \\
\hline Ni1 & $\begin{array}{ll}-1 & \mathrm{Si} \\
-1 & \mathrm{Si} \\
-2 & \mathrm{Si} \\
-2 & \mathrm{Ni} 2 \\
-2 & \mathrm{Ni} 1 \\
-1 & \mathrm{Ni} 3 \\
-1 & \mathrm{Ni} 1 \\
-1 & \mathrm{Ni} 1 \\
-2 & \mathrm{Pr}\end{array}$ & $\begin{array}{l}2.298(4) \\
2.330(3) \\
2.487(3) \\
2.527(1) \\
2.540(1) \\
2.554(1) \\
2.883(1) \\
3.059(1) \\
3.1639(9)\end{array}$ & 13 & & $\mathrm{Si}$ & 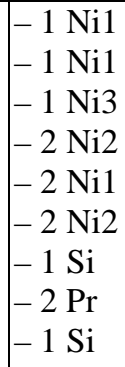 & $\begin{array}{l}2.298(4) \\
2.330(3) \\
2.333(3) \\
2.469(3) \\
2.487(3) \\
2.529(3) \\
2.740(5) \\
3.269(3) \\
3.474(5)\end{array}$ & 13 & \\
\hline$\overline{\mathrm{Ni} 2}$ & $\begin{array}{l}-2 \mathrm{Ni} 2 \\
-1 \mathrm{Ni} 3 \\
-2 \mathrm{Si} \\
-1 \mathrm{Ni} 2 \\
-2 \mathrm{Ni} 1 \\
-2 \mathrm{Si} \\
-2 \mathrm{Pr} \\
-1 \mathrm{Ni} 2\end{array}$ & $\begin{array}{l}2.374(2) \\
2.392(2) \\
2.469(3) \\
2.525(2) \\
2.527(1) \\
2.529(3) \\
3.3217(9) \\
3.357(2)\end{array}$ & 13 & & & & & & \\
\hline
\end{tabular}

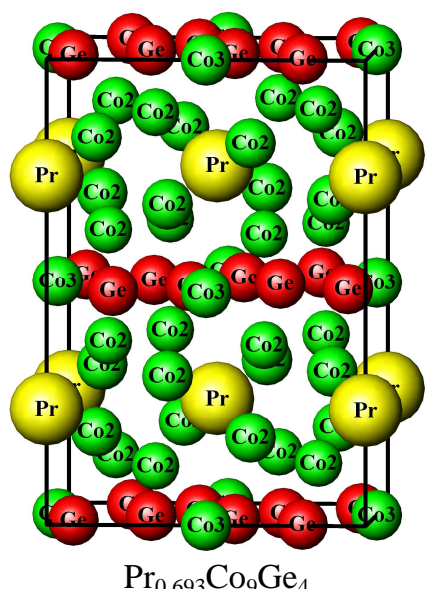

$\mathrm{Pr}_{0.693} \mathrm{Co}_{9} \mathrm{Ge}_{4}$

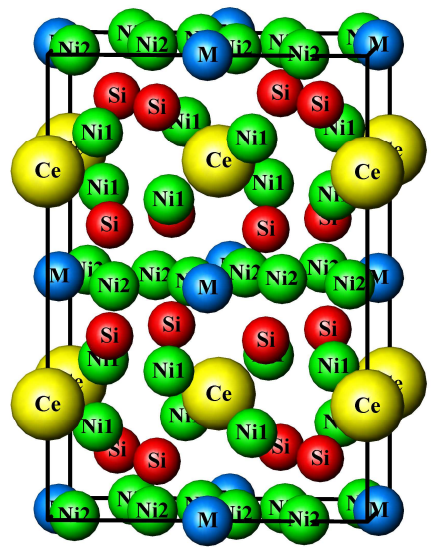

$\mathrm{CeNi}_{8.5} \mathrm{Si}_{4.5}$

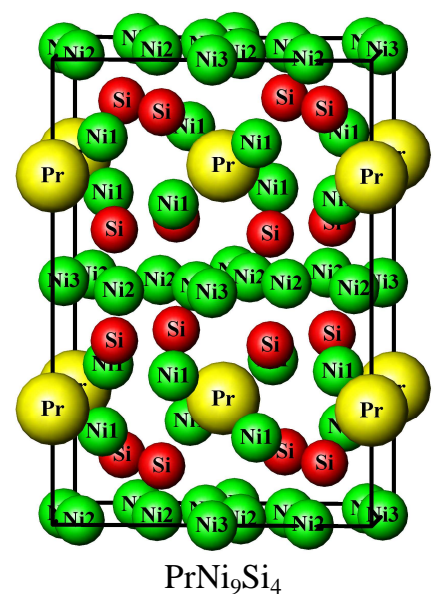

Fig. 1 Atom ordering in the structure of $\mathrm{PrNi}_{9} \mathrm{Si}_{4}$ compound compared with the models proposed for $\operatorname{Pr}_{0.693} \mathrm{Co}_{9} \mathrm{Ge}_{4}$ and $\mathrm{CeNi}_{8.5} \mathrm{Si}_{4.5}$.

According to [2], less than 20 ternary representatives of the cubic structure type $\mathrm{NaZn}_{13}$ have been reported in $R-\{\mathrm{Fe}, \mathrm{Co}, \mathrm{Ni}\}-\mathrm{Si}$ systems $(R=\mathrm{La}, \mathrm{Ce}, \mathrm{Pr}, \mathrm{Nd}$ with $\mathrm{Fe}$ and $\mathrm{Co}, R=\mathrm{Y}, \mathrm{La}, \mathrm{Ce}, \mathrm{Pr}$, $\mathrm{Nd}, \mathrm{Sm}, \mathrm{Eu}, \mathrm{Gd}$, Dy with Ni). In the large majority of the cases only cell parameters have been determined and the parent structure type $\mathrm{NaZn}_{13}$ assigned (space group $F m-3 c$ ). The compound $\mathrm{LaFe}_{11.5} \mathrm{Si}_{1.5}$ has, however, been extensively studied and the structure refined several times. The refinements generally show mixed occupation $\mathrm{Fe} / \mathrm{Si}$ of the site in Wyckoff position $96 i$, whereas the site in $8 b$ is occupied exclusively by $\mathrm{Fe}$ atoms. This type of ordering was reported for the first time for $\mathrm{CaCu}_{6.5} \mathrm{Al}_{6.5}$. The situation for the tetragonal derivatives is similar, in the sense that in most cases only cell parameters have 
been determined and a reliable classification into different substitution variants cannot be made. Complete structure refinements have been reported for 13 compounds in $R-\{\mathrm{Fe}, \mathrm{Co}, \mathrm{Ni}\}-\mathrm{Si}$ systems [2]. The majority of the compounds have the stoichiometry $R T_{9} \mathrm{Si}_{4}$ and show the same kind of ordering as found here, with Si occupying one of the sites in Wyckoff position $16 \mathrm{l}$. The ordering model with the same stoichiometry reported for $\mathrm{Pr}_{0.693} \mathrm{Co}_{9} \mathrm{Ge}_{4}$, where $\mathrm{Ge}$ occupies the site in Wyckoff position 16k, has not been confirmed and a more recent refinement of the structure of $\mathrm{CeCo}_{9} \mathrm{Ge}_{4}$ showed the same type of ordering as observed for the silicides. Differently from the original report on the structure type $\mathrm{CeNi}_{8.5} \mathrm{Si}_{4.5}$, where the excess $\mathrm{Si}$ was found in Wyckoff position $4 d$, more recent refinements on Si-rich compositions in $R-\{\mathrm{Fe}, \mathrm{Co}, \mathrm{Ni}\}-\mathrm{Si}$ systems indicate that the additional $\mathrm{Si}$ atoms preferentially substitute on Wyckoff position $16 k$. It should be noted that a redetermination of the crystal structure of the compound in the $\mathrm{Ce}-\mathrm{Ni}-\mathrm{Si}$ system by Michor et al. [16] showed ordered distribution of all the atoms for the composition $\mathrm{CeNi}_{9} \mathrm{Si}_{4}$. A narrow homogeneity range $\mathrm{CeNi}_{13-x} \mathrm{Si}_{x}$ with $x=4-4.2$ was observed, whereas a wider, off-stoichiometric homogeneity range, $x=4.2-5.5$, was reported in [17]. The content of the unit cell of the structure of the compound $\mathrm{PrNi}_{9} \mathrm{Si}_{4}$ is compared with the ordering models proposed for $\mathrm{Pr}_{0.693} \mathrm{Co}_{9} \mathrm{Ge}_{4}$ and $\mathrm{CeNi}_{8.5} \mathrm{Si}_{4.5}$ in Fig. 1.

The tetragonal structure of $\mathrm{PrNi}_{9} \mathrm{Si}_{4}$ can be described as a 3D packing of two types of polyhedron: 24-vertex pseudo Frank-Kasper polyhedra around the rare-earth element atoms in Wyckoff position $4 a$ and icosahedra around the transition metal atoms in Wyckoff position $4 d$. In the ordered structure of $\mathrm{PrNi}_{9} \mathrm{Si}_{4}$ these polyhedra have the compositions $\left[\mathrm{Ni}_{16} \mathrm{Si}_{8}\right]$ and $\left[\mathrm{Ni}_{8} \mathrm{Si}_{4}\right]$, respectively.

\section{Conclusions}

The crystal structure of the $\mathrm{PrNi}_{9} \mathrm{Si}_{4}$ compound was redetermined by X-ray single-crystal diffraction. The structural parameters are in good agreement with those obtained by X-ray powder diffraction. The structure was found to be fully ordered and can be described as a 3D packing of $\operatorname{Pr}\left[\mathrm{Ni}_{16} \mathrm{Si}_{8}\right]$ pseudo Frank-Kasper polyhedra and $\mathrm{Ni}\left[\mathrm{Ni}_{8} \mathrm{Si}_{4}\right]$ icosahedra.

\section{References}

[1] O.I. Bodak, E.I. Gladyshevskii, Ternary Systems Containing Rare-Earth Metals, Vyshcha Shkola, Lvov, 1985, 328 p. (in Russian).
[2] P. Villars, K. Cenzual (Eds.), Pearson's Crystal Data - Crystal Structure Database for Inorganic Compounds, ASM International, Materials Park, OH, Release 2016/17.

[3] P. Villars, K. Cenzual, R. Gladyshevskii (Eds.), Handbook of Inorganic Substances 2016, De Gruyter, Berlin, 2016, 1877 p.

[4] O.I. Bodak, E.I. Gladyshevskii, Dopov. Akad. Nauk Ukr. SSR 12 (1969) 1125-1129.

[5] E. Zintl, W. Haucke, Z. Elektrochem. Angew. Phys. Chem. 44 (1938) 104-111.

[6] O.I. Bodak, Kristallografiya 24(6) (1979) 1280-1282 (in Russian).

[7] H. Michor, S. Berger, M. El Hagary, C. Paul, E. Bauer, G. Hilscher, P. Rogl, G. Giester, Phys. Rev. B: Condens. Matter 67 (2003) 1-10.

[8] B. Belan, M. Manyako, S. Pukas, Ya. Tokaychuk, R. Gladyshevskii, D. Kaczorowski, Chem. Met. Alloys 7 (2014) 68-73.

[9] B. Belan, S. Pukas, M. Manyako, R. Gladyshevskii, Coll. Abstr. XVI "Lvivski Khimichni Chytannya 2017”, Lviv, 2017, p. H50.

[10] G.M. Sheldrick, Acta Crystallogr. C 71 (2015) 3-8.

[11] E. Dowty, ATOMS - A Computer Program for Displaying Atomic Structures, Kingsport, TN, 1999.

[12] E. Parthé, L. Gelato, B. Chabot, M. Penzo, K. Cenzual, R. Gladyshevskii, TYPIX Standardized Data and Crystal Chemical Characterization of Inorganic Structure Types, Gmelin Handbook of Inorganic and Organometallic Chemistry, SpringerVerlag, Berlin, 1993, Vol. 1, pp. 207-216.

[13] K. Cenzual, R. Gladyshevskii, E. Parthé, TYPIX 1995 Database of Inorganic Structure Types. User's Guide, Gmelin-Institut für Anorganische Chemie, Frankfurt, 1995, $48 \mathrm{p}$.

[14] G. Cordier, E. Czech, H. Schäfer, J. LessCommon Met. 108 (1985) 225-239.

[15] M.F. Fedyna, V.K. Pecharskii, O.I. Bodak, Inorg. Mater. 23 (1987) 504-508.

[16] H. Michor, S. Berger, M. El Hagary, C. Paul, E. Bauer, G. Hilscher, P. Rogl, G. Giester, Phys. Rev. B: Condens. Matter Mater. Phys. 67 (2003), 224428, $10 \mathrm{p}$.

[17] M. Pani, O. Isnard, P. Manfrinetti, A. Provino, F. Yuan, Y.A. Mozharivskyj, A.V. Morozkin, A.V. Knotko, A.V. Garshev, V.O. Yapaskurt, J. Solid State Chem. 210 (2014) 45-52. 